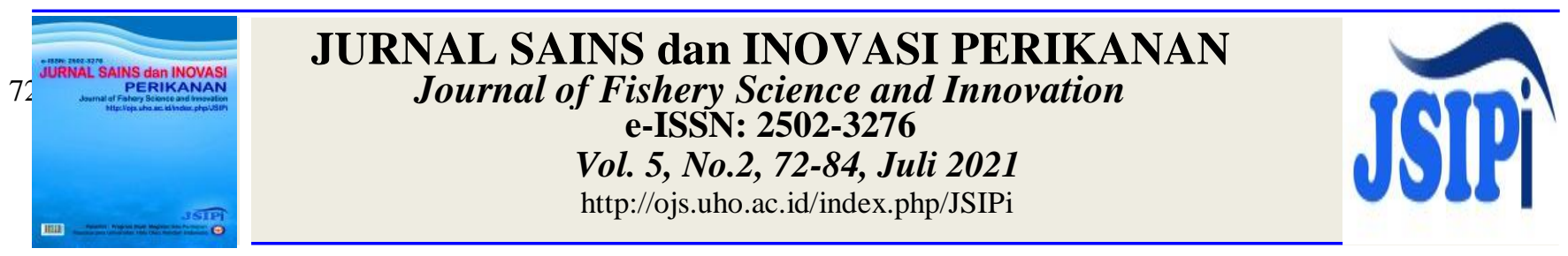

\title{
Pengaruh Pemberian Ekstrak Daun Petai Cina (Leucaena leucocephala) terhadap Performa Udang Vaname (Litopenaeus vannamei)
}

\section{The Effect of Lead Tree Leaf Extract (Leucaena leucocephala) In Diet on The Performance of Vannamei Shrimp (Litopenaeus vannamei)}

\author{
Nurul Pratiwi ${ }^{1}$, Salnida Yuniarti Lumbessy ${ }^{1 * *}$, Fariq Azhar ${ }^{1 \text { ) }}$ \\ ${ }^{1)}$ Program Studi Budidaya Perairan, Fakultas Pertanian, Universitas Mataram, Mataram, Indonesia \\ Corresponding author ${ }^{*}$ : salnidayuniarti@unram.ac.id
}

\begin{abstract}
The main problem in vaname shrimp cultivation is disease attack that causes shrimp growth to be less than optimal. This study aims to analyze the effect of lead tree leaf extract (L. leucocephala) on the performance of vannamei shrimp (L. vannamei). This study was conducted for 60 days using PL-20 sized vannamei shrimp. The method used in this study was an experimental method with a Completely Randomized Design (CRD) consisting of 4 treatments and 3 replications, namely, P1: without the addition of lead tree leaf extract (control), P2: 1\% v/w lead tree leaf extract, P3: $2 \% \mathrm{v} / \mathrm{w}$ lead tree leaf extrac and P4: $3 \% \mathrm{v} / \mathrm{w}$ lead tree leaf extrac. The results of this study indicate that the addition of lead tree leaf extract with different doses to vannamei shrimp feed has a significant effect on the growth and FCR value of vannamei shrimp, but does not affect the survival rate (SR) of vannamei shrimp. It is suspected that the lead tree leaf extract contains glycerin, erythritol and inositol compounds. The addition of lead tree leaf extract up to a dose of $2 \% \mathrm{v} / \mathrm{w}$ can give an increase in absolute weight $3.70 \mathrm{~g}$, absolute length $6.13 \mathrm{~cm}$, specific growth rate (SGR) $5.7 \mathrm{~g} /$ day and feed conversion ratio (FCR) 0.9. Therefore, the lead tree leaf extract has the potential to be used as a non-nutritive feed additive in vannamei shrimp culture.
\end{abstract}

Keywords: Lead Tree Extract, Performa, Vannamei Shrimp

\begin{abstract}
ABSTRAK
Permasalahan utama dalam budidaya udang vaname adalah serangan penyakit yang menyebabkan pertumbuhan udang menjadi kurang optimal. Penelitian ini bertujuan untuk menganalisis pengaruh ekstrak daun petai cina $(L$. leucocephala) terhadap performa udang vaname (L. vannamei). Penelitian ini dilakukan selama 60 hari menggunakan udang vaname berukuran PL-20. Metode yang digunakan pada penelitian ini adalah metode eksperimental dengan Rancangan Acak Lengkap (RAL) yang terdiri atas 4 perlakuan dan 3 ulangan yaitu, P1: tanpa penambahan ekstrak daun petai cina (kontrol), P2: ekstrak daun petai cina $1 \% \mathrm{v} / \mathrm{w}, \mathrm{P} 3$ : ekstrak daun petai cina $2 \%$ v/w dan P4: ekstrak daun petai cina 3\% v/w.. Hasil penelitian ini menunjukkan bahwa penambahan ekstrak daun petai cina dengan dosis yang berbeda pada pakan udang vaname memberikan pengaruh yang nyata terhadap pertumbuhan dan nilai FCR udang vaname, tetapi tidak mempengaruhi tingkat kelangsungan hidup (SR) udang vaname. Diduga bahwa ekstrak daun petai cina mengandung senyawa glycerin, erythritol dan inositol. Penambahan ekstrak daun petai cina sampai dengan dosis $2 \% \mathrm{v} / \mathrm{w}$ dapat memberikan peningkatan bobot mutlak $3,70 \mathrm{~g}$, panjang mutlak $6,13 \mathrm{~cm}$, laju pertumbuhan spesifik (SGR) $5,7 \mathrm{~g} /$ hari dan rasio konversi pakan (FCR) 0,9 . Oleh karena itu ekstrak daun petai cina mempunyai potensi untuk dimanfaatkan sebagai feed additive non nutritif pada budidaya udang vaname..
\end{abstract}

Kata Kunci: Ekstrak Petai Cina, Performa, Udang Vaname 


\section{DOI: http://dx.doi.org/10.33772/jspi.v5n2}

\section{PENDAHULUAN}

Udang merupakan salah satu komoditas unggulan Indonesia yang paling diminati karena memiliki kandungan gizi dan nilai ekonomi tinggi serta mempunyai peluang pasar baik di dalam maupun di luar negeri. Nilai ekspor udang selama tahun 20122017 mengalami kenaikan tiap tahunnya, yaitu sebesar 10,40\% per tahun (Kementerian Kelautan dan Perikanan, 2018). Salah satu jenis udang yang menjadi komoditas unggulan dari sektor perikanan adalah udang vaname (Litopenaeus vannamei). Sampai saat ini udang vaname masih menjadi komoditas andalan karena memiliki daya toleransi yang tinggi terhadap perubahan kondisi lingkungan, pertumbuhannya yang cepat, dan relatif tahan terhadap serangan penyakit bila dibandingkan dengan udang windu. Namun tidak dapat dihindari bila penyakit masih menjadi permasalahan utama dalam kegiatan budidaya udang vaname.

Penyakit dapat menyebabkan kualitas biota yang dibudidayakan menurun bahkan dapat mengalami kematian sehingga tingkat kelangsungan hidup udang vaname menjadi rendah. Dampak dari penyakit ini dapat berupa kurangnya nafsu makan udang hingga kematian dalam skala besar. Timbulnya penyakit pada udang dapat disebabkan oleh virus maupun bakteri. Bakteri yang sering menginfeksi udang vaname adalah Vibrio sp. yang menyebabkan penyakit vibriosis sehingga banyak menimbulkan kerugian ekonomi pada budidaya udang vaname (Setyono, et. al., 2019). Bakteri ini akan menghambat pertumbuhan udang bahkan dapat menyebabkan kematian massal. Infeksi vibrio ini dapat terjadi pada semua fase (telur sampai indukan) dan banyak menyebabkan kasus kematian organisme budidaya sampai $100 \%$ (Kusumaningrum et al., 2017).

Untuk meminimalkan tingkat kematian pada udang akibat baktri Vibrio sp. ini maka perlu dilakukan upaya pencegahan dan penanganan pada udang. Salah satunya adalah dengan menggunakan antibiotik sintetis. Namun, penggunaan antibiotik sintetis dapat menimbulkan adanya efek samping bagi udang karena dapat menyebabkan residu yang dapat mencemari lingkungan sehingga kualitas air menjadi buruk dan jika digunakan secara berkelanjutan menyebabkan organisme menjadi resisten dan berbahaya (Suci, 2018). Oleh karena itu, sebagai alternatif untuk menekan pertumbuhan bakteri Vibrio sp. dengan menggunakan antibiotik alami yang berasal dari bahan herbal seperti daun petai cina (Leucaena leucocephala).

Petai cina merupakan tumbuhan yang mengandung senyawa metabolit sekunder (Hanafi et. al., 2012). Daun petai cina mengandung zat aktif berupa alkaloid, saponin, flavonoid, mimosin, lektin, protein, lemak, kalsium, fosfor, zat besi, vitamin A dan vitamin B. Kandungan saponin pada daun petai cina berperan sebagai antiinflamasi. Sementara lektin berperan dalam mestimulasi pertumbuhan sel kulit, dan antibiotik yang terdapat dalam saponin berperan sebagai penghambat pertumbuhan bakteri (Praja dan Oktarlina, 2016). Oleh karena itu, maka daun petai cina ini memiliki potensi sebagai antibiotik alami yang diharapkan dapat mencegah penyakit vibriosis pada udang.

Beberapa hasil penelitian terdahulu melaporkan bahwa penggunaan daun petai cina ini dapat meningkatkan pertumbuhan harian ikan mujair sebesar 2,2\% dengan kadar protein sebanyak 50\% (Kurniasih, 2012). Selain itu, penggunaan fermentasi tepung daun petai cina juga memberikan pengaruh terhadap pertumbuhan, efisiensi pakan dan kecernaan pakan ikan bawal air tawar (Lubis, 2018). Ekstrak daun petai cina memiliki kandungan yang sama dengan daun mangrove dimana mampu mempertahankan Survival Rate (SR) sebesar 76,67\%, meningkatkan Differential Haemocyte Count (THC) udang sebesar $7,55 \times 10^{6} \mathrm{sel} / \mathrm{ml}$ dan Differential Haemocyte Count (DHC) (sel hialin $84,3 \%$ dan granular $15,3 \%$ ) yang berperan dalam sistem imun udang pada dosis $2 \%$ (Fadillah, et. al., 2019).

Berdasarkan uraian di atas maka penelitian ini dilakukan untuk menganalisa pengaruh pemberian ekstrak daun petai cina pada pakan dengan dosis yang berbeda terhadap performa pertumbuhan udang vaname. Pemberian dosis yang tepat diharapkan dapat mempengaruhi aktifitas bakteri vibrio sp. yang penyebab penyakit vibriosis pada udang, sehingga dapat meningkatkan performa pertumbuhan udang vaname. 
74 Nurul Pratiwi et al.

JURNAL SAINS dan INOVASI PERIKANAN / Journal of Fishery Science and Innovation Vol. 5, No. 2, Juli 2021

\section{METODE PENELITIAN}

Penelitian ini dilaksanakan selama 60 hari di Laboratorium Budidaya Perairan, Jurusan Perikanan dan Ilmu Kelautan, Fakultas Pertanian, Universitas Mataram. Proses ekstraksi dilakukan di Laboratorium Kimia, Fakultas Matematika dan Ilmu Pengetahuan Alam, Universitas Mataram. Analisa Proksimat Pakan dilakukan di Laboratorium Ilmu Nutrisi dan Makanan Ternak, Fakultas Peternakan, Universitas Mataram.

Penelitian ini menggunakan metode eksperimental dengan menggunakan Rancangan Acak Lengkap (RAL) yang terdiri atas 4 perlakuan konsentrasi ekstrak daun petai cina yang ditambahkan pada pakan. Masing-masing perlakuan dilakukan 3 kali ulangan sehingga diperoleh 12 unit percobaan. Perlakuan yang diberikan adalah:

P1 : tanpa penambahan ekstrak daun petai cina (kontrol)

$\mathrm{P} 2$ : ekstrak daun petai cina $1 \% \mathrm{v} / \mathrm{w}$

P3 : ekstrak daun petai cina $2 \% \mathrm{v} / \mathrm{w}$

P4 : ekstrak daun petai cina $3 \% \mathrm{v} / \mathrm{w}$

\section{Prosedur Penelitian}

Udang vaname ( $L$. vannamei) yang digunakan dalam penelitian ini berukuran PL10. Udang dilakukan aklimatisasi di bak beton berukuran 300x150x80 cm selama 10 hari. Wadah pemeliharaan yang digunakan dalam penelitian ini adalah bak kontainer berukuran $39 \times 27 \times 24,7 \mathrm{~cm}$. Selanjutnya udang ditebar dengan padat tebar 20 ekor/kontainer

\section{Pembuatan Ekstrak Daun Petai Cina ( $L$. leucocephala)}

Daun petai cina (L. leucocephala) yang digunakan yaitu daun petai cina tua. Daun petai cina dicuci menggunakan air bersih dan dikeringkan dengan oven pada suhu $60^{\circ} \mathrm{C}-70^{\circ} \mathrm{C}$. Setelah kering, daun dihaluskan menggunakan blender sampai menjadi bubuk kemudian dilakukan pengayakan untuk mendapatkan bubuk halus. Bubuk daun petai cina ditimbang sebanyak $1 \mathrm{~kg}$ dan dimaserasi di dalam toples kaca dengan pelarut etanol $96 \%$ sebanyak 4 L sampai seluruh bubuk terendam. Simplisia diaduk dan kemudian didiamkan selama $1 \times 72$ jam pada suhu ruang dan diletakkan di ruang gelap yang terlindung langsung dari cahaya. Hasil maserasi kemudian disaring menggunakan corong kaca dan kertas saring. Ekstrak cair yang diperoleh diuapkan dengan rotary evaporator pada temperatur $\pm 45{ }^{\circ} \mathrm{C}$ sampai dihasilkan ekstrak kental.

Pakan yang digunakan dalam pemeliharaan adalah pellet komersial merk $\mathrm{CP}$ Prima yang memiliki kandungan protein sebanyak $40 \%$. Jumlah pakan yang diberikan ditentukan dengan menghitung bobot biomassa pada udang dan dikali dengan persentase kebutuhan pakan sebanyak 5\%. Selanjutnya pakan dicampurkan dengan ekstrak daun petai cina. Pencampuran ekstrak daun petai cina ini dilakukan dengan cara diteteskan ke dalam pakan menggunakan mikropipet sesuai dengan perlakuan yang ada. Kemudian pakan yang telah dicampur ekstrak daun petai cina tersebut dihomogenkan dengan menggunakan sendok hingga tercampur rata ke seluruh pakan.

\section{Pelaksanaan Penelitian}

Bak kontainer diisi dengan air laut sebanyak 20 L. Air laut yang digunakan diendapkan terlebih dahulu pada bak penampung berukuran 300x150x80 cm.Udang vaname yang digunakan pada saat penelitian yaitu pada fase PL-20. Setiap akuarium diisi dengan hewan uji sebanyak 20 ekor dan wadah yang digunakan dilengkapi dengan perangkat aerasi, shelter dan sistem pergantian air setiap satu kali sehari secara berkala sebanyak $10 \%$ dari volume total akuarium. Udang yang akan ditebar harus diseleksi terlebih dahulu. Seleksi yang dilakukan yaitu dengan memilih benih yang sehat, berukuran seragam, memiliki pergerakan yang aktif dan berenang secara menyebar.

\section{Pemberian Pakan dan Manajemen Kualitas Air}

Udang diberi pakan sebanyak $5 \%$ dari berat biomassa tiap container sesuai perlakuan yang ada. Pemberian pakan dilakukan sebanyak 4 kali sehari yaitu pada pukul 08.00; 12.00; 17.00 dan 21.30 WITA. Penyiponan dilakukan setiap hari selama pemeliharaan. Penyiponan dilakukan pada pukul 11.00 WITA sebanyak $10 \%$ dari volume total akuarium. Pengukuran kualitas air dilakukan setiap 15 hari sekali.

\section{Parameter Penelitian}

Uji Gas Chromatography Mass Spectrometry (GCMS)

Ekstrak daun petai cina hasil maserasi dan evaporasi dilarutkan menggunakan aseton kemudian dianalisis dengan GC-MS (Gass Chromatography - 
Mass Spectrometer) menggunakan protokol standar untuk mendapatkan senyawa aktif

\section{Analisis Proksimat Pakan}

Analisis proksimat merupakan uji analisis suatu bahan pakan dan dapat digunakan untuk menduga nilai nutrisi dan nilai energi dari bahan atau campuran pakan yang berasal dari bagian komponen bahan pakan tersebut (Isharyudono et. al., 2019). Analisa proksimat dilakukan pada pakan komersial yang telah dicampurkan dengan ekstrak daun petai cina sesuai perlakuannya untuk mengetahui kandungan protein, karbohidrat, air, abu, lemak dan serat kasar.

\section{Kelangsungan Hidup (SR)}

Tingkat kelangsungan hidup adalah persentase udang yang hidup dari jumlah seluruh udang yang dipelihara dalam suatu wadah atau perbandingan antara jumlah udang yang hidup pada saat tebar serta pada saat akhir masa pemeliharaan.

Tingkat kelangsungan hidup dapat dihitung dengan menggunakan rumus sebagai berikut (Azhar 2013) : :

$$
S R=\frac{N t}{N o} \times 100 \%
$$

Keterangan:

SR: Tingkat kelangsungan hidup (\%)

$\mathrm{Nt}$ : Jumlah udang yang hidup diakhir pemeliharaan (ekor)

No: Jumlah udang yang hidup diawal pemeliharaan (ekor)

\section{Rasio Konversi Pakan (FCR)}

Perhitungan Rasio Konversi Pakan (FCR) akan dilakukan pada akhir penelitian untuk melihat perbandingan jumlah pakan yang dimakan selama masa pemeliharaan. Menurut Oktaviana (2014), rasio konversi pakan selama penelitian dapat dihitung dengan menggunakan rumus sebagai berikut:

$$
F C R=\frac{F}{(B t+B m)-B o}
$$

Keterangan:

FCR : Rasio konversi pakan

F : Jumlah pakan $(\mathrm{g})$

Bt : Biomassa udang pada akhir penelitian $(\mathrm{g})$

$\mathrm{Bm} \quad$ : Biomassa udang yang mati $(\mathrm{g})$

Bo : Biomassa udang pada awal penelitian $(\mathrm{g})$

\section{Laju Pertumbuhan Spesifik (SGR)}

Laju pertumbuhan spesifik adalah persentase pertambahan berat udang setiap harinya selama pemeliharaan. Pengukuran pertumbuhan berat sebagai data persentase pertumbuhan udang yang diukur tiap 10 hari sekali untuk mengetahui pengaruh pemberian ekstrak daun petai cina.

Laju pertumbuhan spesifik udang dihitung dengan menggunakan rumus sebagai berikut (Azhar 2013) :

$$
S G R(\%)=\frac{\operatorname{In} W t-\operatorname{In} W o}{t} \times 100 \%
$$

Keterangan:

SGR : Laju pertumbuhan spesifik

Wo: Bobot tubuh pada awal pemeliharaan $(\mathrm{g})$

Wt: Bobot tubuh pada akhir pemeliharaan $(\mathrm{g})$

t : Waktu pemeliharaan (hari)

\section{Pertumbuhan Bobot Mutlak (Wm)}

Pertumbuhan Bobot Mutlak dihitung untuk mendapatkan pertambahan bobot biota yang dipelihara setiap harinya. Menurut Pratama et. al., (2017), Pertumbuhan Bobot Mutlak (Wm) dapat dihitung dengan menggunakan rumus sebagai berikut:

$$
W=W t-W o
$$

Keterangan:

W: Pertumbuhan bobot individu mutlak hewan uji $(\mathrm{g})$ Wt: Bobot udang pada akhir penelitian $(\mathrm{g})$

Wo: Bobot udang pada awal penelitian (g)

\section{Pertambahan Panjang Mutlak (Pm)}

Pertambahan panjang mutlak merupakan selisih antara panjang pada ikan antara ujung kepala hingga ujung ekor tubuh pada akhir penelitian dengan panjang tubuh pada awal penelitian. Pertambahan panjang mutlak dihitung dengan menggunakan rumus (Mulqan et. al., 2017) :

$$
\mathrm{Pm}=\mathrm{Lt}-\mathrm{Lo}
$$

Keterangan:

Pm : Pertambahan panjang mutlak $(\mathrm{cm})$

Lt : Panjang rata-rata akhir $(\mathrm{cm})$

Lo : Panjang rata-rata awal $(\mathrm{cm})$

\section{Analisis Data}

Data GC-MS dan proksimat pakan dianalisa secara deskriptif. Sementara data performa udang vaname yang diperoleh dianalisis menggunakan Analisis Varian (ANNOVA) dengan SPSS pada taraf 
76 Nurul Pratiwi et al.

JURNAL SAINS dan INOVASI PERIKANAN / Journal of Fishery Science and Innovation

Vol. 5, No. 2, Juli 2021

signifikan 5\% untuk mengetahui pengaruh dari perlakuan berbagai konsentrasi ekstrak daun petai cina yang digunakan. Selanjutnya semua parameter performa udang vaname tersebut dianalisa lanjut dengan uji Beda Nyata Terkecil (BNT), kecuali untuk parameter kelangsungan hidup (survival rate).

\section{HASIL}

Uji Gas Chromatography Mass Spectrometry (GCMS)

Hasil uji GC-MS ekstrak daun petai cina menunjukkan bahwa terdapat 15 peak yang terdeteksi. Namun hanya 6 senyawa saja yang teridentifikasi (Gambar 1.). Senyawa-senyawa yang berhasil terindentifikasi tersebut dapat dilihat pada Tabel 1.
Profil GC-MS ekstrak etanol daun petai cina menunjukkan adanya 1,2,3-Propanetriol (41,27\%) sebagai konstituen utama; kemudian diikuti oleh 1,2,3,4-Tetrahydroxybutane $(21,66 \%)$ dan mome inositol $(11,05 \%)$ [Tabel 1].

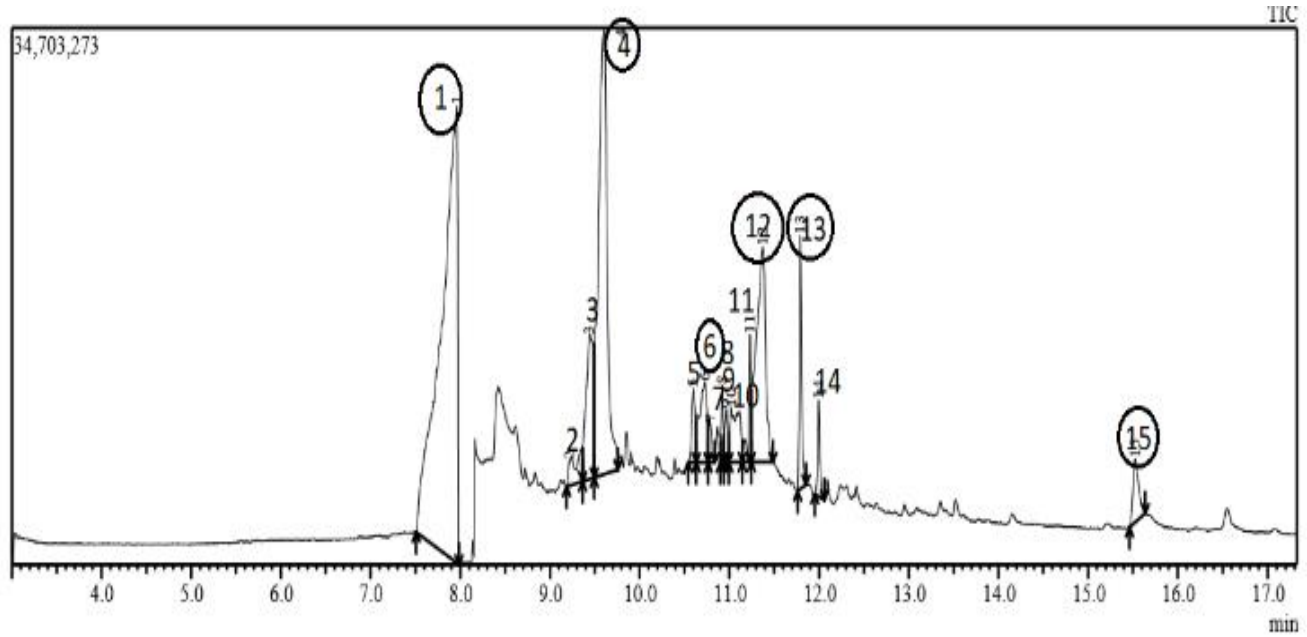

Gambar 1. Hasil uji GC-MS ekstrak daun petai cina

Tabel 1. Senyawa pada ekstrak daun petai cina hasil uji GC-MS

\begin{tabular}{|c|c|c|c|c|c|c|}
\hline Peak & Nama Senyawa & $\begin{array}{l}\text { Golongan } \\
\text { Senyawa }\end{array}$ & Nama Lain & $\begin{array}{l}\text { Rumus } \\
\text { Molekul }\end{array}$ & $\begin{array}{l}\text { Waktu } \\
\text { Retensi }\end{array}$ & $\%$ Area \\
\hline 1 & $\begin{array}{l}\text { 1,2,3-Propanetriol (Cas) } \\
\text { Glycerol }\end{array}$ & Alkohol & Glycerin & $\mathrm{C}_{3} \mathrm{H}_{8} \mathrm{O}_{3}$ & 7.963 & 41,27 \\
\hline 4 & $\begin{array}{l}1,2,3,4- \\
\text { Tetrahydroxybutane }\end{array}$ & Gula Alkohol & Erythritol & $\mathrm{C}_{4} \mathrm{H}_{10} \mathrm{O}_{4}$ & 9.604 & 21,66 \\
\hline 6 & Xylitol (Cas) Xylite & Gula Alkohol & Xylitol & $\mathrm{C}_{5} \mathrm{H}_{12} \mathrm{O}_{5}$ & 10.726 & 3,39 \\
\hline 12 & Mome Inositol & Polisakarida & Inositol & $\mathrm{C}_{7} \mathrm{H}_{14} \mathrm{O}_{6}$ & 11.373 & 11,05 \\
\hline 13 & $\begin{array}{l}\text { (-)-Loliolide } \\
\text { 2-Cyclohexen-1-One, 4- }\end{array}$ & monoterpenoid & Loliolide & $\mathrm{C}_{11} \mathrm{H}_{16} \mathrm{O}_{3}$ & 11.994 & 3,14 \\
\hline 15 & $\begin{array}{l}\text { Hydroxy-3,5,5- } \\
\text { Trimethyl-4-(3-Oxo-1- } \\
\text { Butenyl)- }\end{array}$ & Lipid & Dehydrovomifoliol & $\mathrm{C}_{13} \mathrm{H}_{18} \mathrm{O}_{3}$ & 15.524 & 2,01 \\
\hline
\end{tabular}


Vol. 5, No. 2. 72- 84, Juli 2021

\section{Analisis Proksimat Pakan}

Hasil analisis proksimat pakan komersial udang vaname (L. vannamei) dengan berbagai konsentrasi ekstrak daun petai cina (L. leucocephala) pada penelitian ini menunjukkan hasil yang bervariasi (Tabel 2).

Tabel 2. Hasil uji proksimat pakan komersial udang vaname (L. vannamei) dengan berbagai konsentrasi ekstrak daun petai cina (L. leucocephala).

Tabel 2. Analisis proksimat pakan

\begin{tabular}{ccccccc}
\hline Kode & Air $(\%)$ & Abu $(\%)$ & $\begin{array}{c}\text { Lemak } \\
\text { Kasar } \\
(\%)\end{array}$ & $\begin{array}{c}\text { Serat } \\
\text { Kasar } \\
(\%)\end{array}$ & $\begin{array}{c}\text { Protein } \\
\text { Kasar }(\%)\end{array}$ & $\begin{array}{c}\text { Karbohidrat } \\
(\% \text { w/b })\end{array}$ \\
\hline P1 & 8,16 & 8,65 & 8,01 & 0,62 & 34,00 & $41,16 \%$ \\
P2 & 8,13 & 9,19 & 8,04 & 1,53 & 34,41 & $40,21 \%$ \\
P3 & 9,03 & 7,40 & 8,07 & 2,67 & 35,16 & $40,32 \%$ \\
P4 & 9,17 & 8,07 & 8,14 & 2,88 & 36,26 & $38,34 \%$ \\
\hline
\end{tabular}

Ket: P1 (kontrol), P2 (ekstrak daun petai cina 1\% v/w), P3 (ekstrak daun petai cina 2\% v/w), P4 (ekstrak daun petai cina $3 \% \mathrm{v} / \mathrm{w})$.

Tabel 2. menunjukkan bahwa semua perlakuan kontrol maupun perlakuan pemberian ekstrak daun petai cina memberikan nilai proksimat pakan udang vaname yang sesuai dengan standar proksimat pakan udang SNI 7813:2013, kecuali kadar protein dan kadar lemak. Menurut SNI 7813:2013 bahwa standar proksimat pakan untuk pembesaran benih udang vaname PL 1-10 adalah kadar air maksimal $12 \%$, kadar abu maksimal $12 \%$, kadar protein minimal $43 \%$, kadar lemak minimal $6 \%$ dan untuk kadar serat kasar maksimal $6 \%$.

\section{Kelangsungan Hidup (SR)}

Hasil penelitian menunjukkan bahwa tingkat kelangsungan hidup udang vaname selama 60 hari masa pemeliharaan dengan pemberian pakan komersial pada berbagai perlakuan ekstrak daun petai cina berkisar antara 55\%-63\% (Gambar 2).

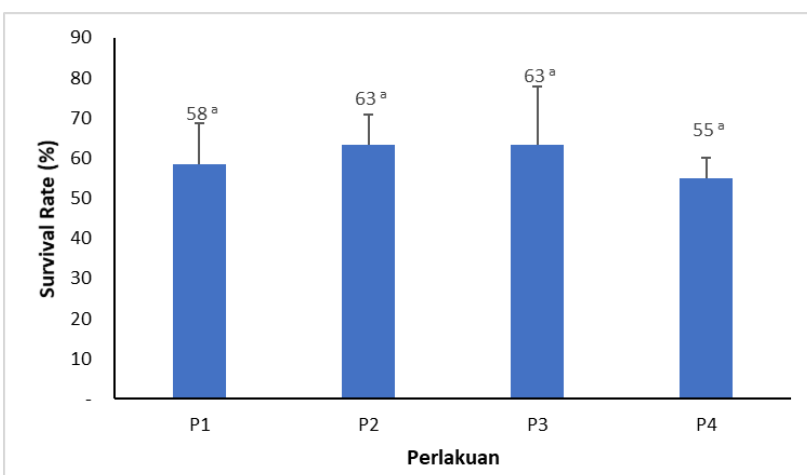

Gambar 2. Rata-rata tingkat kelangsungan hidup udang vaname (L. vannamei) pada pemberian pakan dengan berbagai perlakuan ekstrak daun petai cina
(L. leucocephala). P1 (kontrol) ; P2 (ekstrak daun petai cina $1 \% \mathrm{v} / \mathrm{w}$ ) ; P3 (ekstrak daun petai cina $2 \%$ $\mathrm{v} / \mathrm{w}) ; \mathrm{P} 4$ (ekstrak daun petai cina 3\% v/w).

\section{Rasio Konversi Pakan (FCR)}

Hasil penelitian menunjukkan bahwa rasio konversi pakan udang vaname selama 60 hari masa pemeliharaan dengan pemberian pakan komersial pada berbagai perlakuan ekstrak daun petai cina berkisar antara 0,7-1 (Gambar 3).

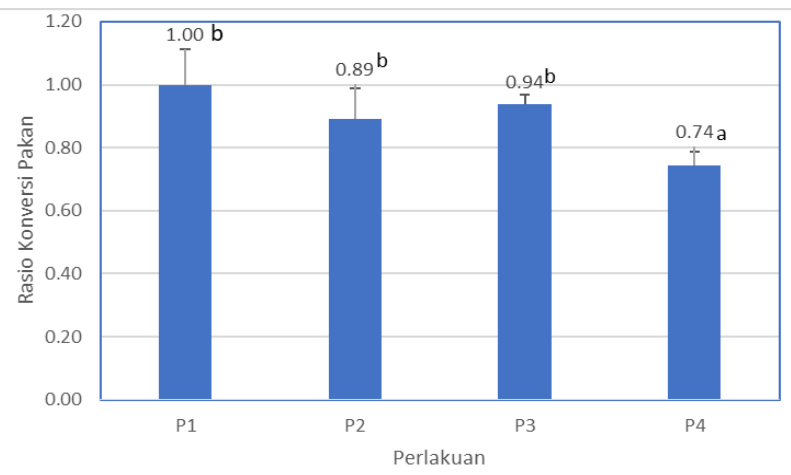

Gambar 3. Rata-rata rasio konversi pakan udang vaname ( $L$. vannamei) pada pemberian pakan komersial dengan berbagai perlakuan ekstrak daun petai cina (Ll. leucocephala). P1 (kontrol) ; P2 (ekstrak daun petai cina 1\% v/w) ; P3 (ekstrak daun petai cina $2 \% \mathrm{v} / \mathrm{w}) ; \mathrm{P} 4$ (ekstrak daun petai cina $3 \%$ $\mathrm{v} / \mathrm{w})$.

\section{Laju Pertumbuhan Spesifik (SGR)}

Hasil penelitian menunjukkan bahwa Laju Pertumbuhan Spesifik udang vaname selama 60 hari 
78 Nurul Pratiwi et al.

JURNAL SAINS dan INOVASI PERIKANAN / Journal of Fishery Science and Innovation Vol. 5, No. 2, Juli 2021

masa pemeliharaan dengan pemberian pakan komersial pada berbagai perlakuan ekstrak daun petai cina berkisar antara 5.0\%-5.8\% (Gambar 4).

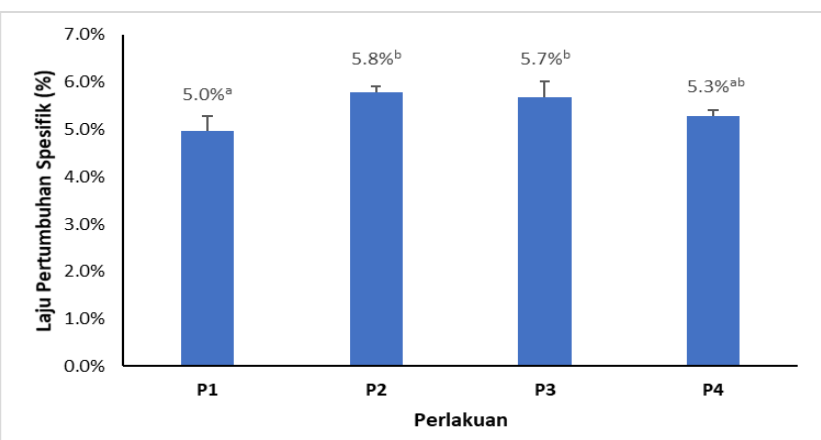

Gambar 4. Rata-rata laju pertumbuhan spesifik udang vaname ( $L$. vannamei) pada pemberian pakan komersial dengan berbagai perlakuan ekstrak daun petai cina (Ll. leucocephala). P1 (kontrol) ; P2 (ekstrak daun petai cina 1\% v/w) ; P3 (ekstrak daun petai cina $2 \% \mathrm{v} / \mathrm{w}) ; \mathrm{P} 4$ (ekstrak daun petai cina $3 \%$ $\mathrm{v} / \mathrm{w})$.

\section{Pertumbuhan Bobot Mutlak}

Hasil penelitian menunjukkan bahwa pertumbuhan bobot mutlak udang vaname selama 60 hari masa pemeliharaan dengan pemberian pakan komersial pada berbagai perlakuan ekstrak daun petai cina berkisar antara 2,23 - 3,70 g (Gambar 5).

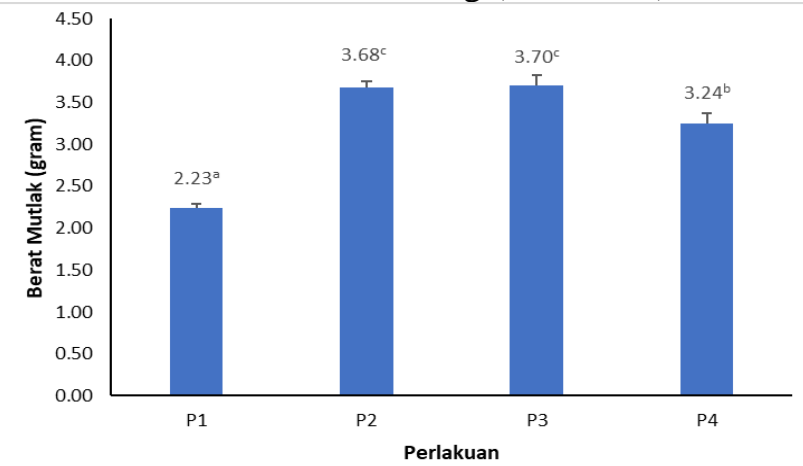

Gambar 5. Rata-rata pertumbuhan bobot mutlak udang vaname (L. vannamei) pada pemberian pakan komersial dengan berbagai perlakuan ekstrak daun petai cina (L. leucocephala). P1 (kontrol) ; P2 (ekstrak daun petai cina 1\% v/w) ; P3 (ekstrak daun petai cina $2 \% \mathrm{v} / \mathrm{w}$ ) ; P4 (ekstrak daun petai cina $3 \%$ $\mathrm{v} / \mathrm{w})$.

\section{Pertambahan Panjang Mutlak}

Hasil penelitian menunjukkan bahwa pertambahan panjang mutlak udang vaname selama
60 hari masa pemeliharaan dengan pemberian pakan komersial pada berbagai perlakuan ekstrak daun petai cina berkisar antara 4,64 cm-6,13 cm (Gambar 6).

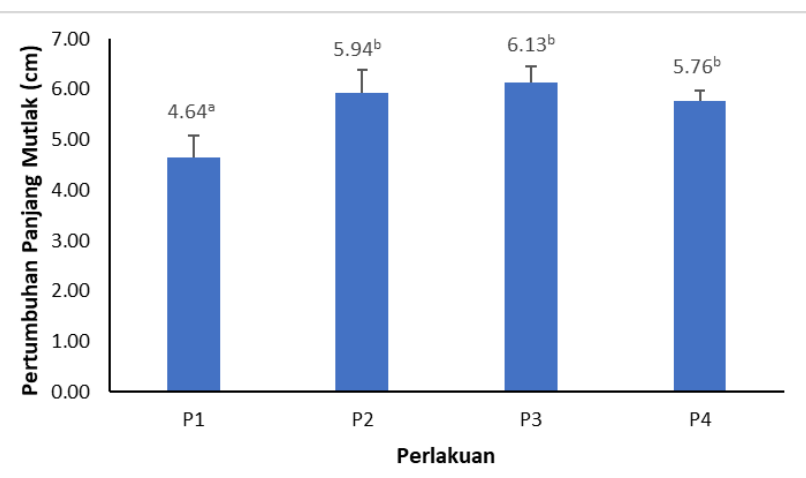

Gambar 6. Pertambahan panjang mutlak udang vaname (L. vannamei) pada pemberian pakan komersial dengan berbagai perlakuan ekstrak daun petai cina (L. leucocephala). P1 (kontrol) ; P2 (ekstrak daun petai cina 1\% v/w) ; P3 (ekstrak daun petai cina $2 \% \mathrm{v} / \mathrm{w}$ ) ; P4 (ekstrak daun petai cina 3\% $\mathrm{v} / \mathrm{w})$.

\section{Kualitas Air}

Hasil pengamatan kualitas air udang vaname selama 60 hari masa pemeliharaan menunjukkan bahwa nilai kisaran suhu, $\mathrm{pH}$, DO, dan salinitas masih berada dalam batas kelayakan pemeliharaan udang vaname (Tabel 3).

Tabel 3. Kualitas air pemeliharaan udang vaname ( $L$. vannamei) pada berbagai perlakuan ekstrak daun petai cina (L. leucocephala).

\begin{tabular}{|c|c|c|c|c|c|}
\hline \multirow{2}{*}{ Parameter } & \multicolumn{4}{|c|}{ Perlakuan } & \multirow{2}{*}{$\begin{array}{c}\text { Pustaka } \\
\text { Kelayakan }\end{array}$} \\
\hline & P1 & $\mathrm{P} 2$ & P3 & $\mathrm{P} 4$ & \\
\hline & $\begin{array}{l}27,5- \\
28,3\end{array}$ & $\begin{array}{l}27,5- \\
28,2\end{array}$ & $\begin{array}{l}27,4- \\
28,3\end{array}$ & $\begin{array}{l}27,5- \\
28,3\end{array}$ & $\begin{array}{c}28-31^{0} \mathrm{C} \\
\text { (Purnamasari, } \\
2017^{\mathrm{a}} \text { ) }\end{array}$ \\
\hline $\mathrm{pH}$ & $\begin{array}{l}7,9- \\
8,1\end{array}$ & $\begin{array}{l}7,8- \\
8,1\end{array}$ & $\begin{array}{l}7,9- \\
8,2\end{array}$ & $\begin{array}{l}7,9- \\
8,2\end{array}$ & $\begin{array}{c}7,5-8,5 \\
\text { (Purnamasari, } \\
2017^{\mathrm{a}} \text { ) }\end{array}$ \\
\hline $\begin{array}{c}\mathrm{DO} \\
(\mathrm{mg} / \mathrm{l})\end{array}$ & $\begin{array}{l}6,9- \\
7,8\end{array}$ & $\begin{array}{l}7,1- \\
7,8\end{array}$ & $\begin{array}{l}6,8- \\
7,9\end{array}$ & $\begin{array}{l}7,1- \\
7,9\end{array}$ & $\begin{array}{c}4-8 \mathrm{mg} / \mathrm{l} \\
\text { (Purnamasari, } \\
2017^{\mathrm{b}} \text { ) }\end{array}$ \\
\hline $\begin{array}{l}\text { Salinitas } \\
\text { (ppt) }\end{array}$ & $\begin{array}{l}29- \\
33\end{array}$ & $\begin{array}{c}30- \\
34\end{array}$ & $\begin{array}{l}28- \\
34\end{array}$ & $\begin{array}{l}29- \\
34\end{array}$ & $\begin{array}{c}10-30 \text { ppt } \\
\text { (Kordi, 2007) }\end{array}$ \\
\hline
\end{tabular}




\section{PEMBAHASAN}

Nutrien dalam jumlah tertentu sangat dibutuhkan udang vaname untuk bertumbuh dan maintenance (pemeliharaan) serta mempertahankan tubuh dari berbagai penyakit. Beberapa faktor yang mempengaruhi pertumbuhan udang dapat dikelompokkan menjadi : (1) faktor internal (dari dalam) yang terdiri atas faktor genetika dan fisiologi udang, misalnya tingkat kesehatan serta (2) faktor eksternal (dari luar), seperti pakan, padat tebar dan a kualitas air (pH, suhu, salinitas, DO, dll) (Febriani et. al., 2018). Hasil penelitian ini menunjukkan bahwa ekstrak daun petai cina yang ditambahkan pada pakan udang vaname dengan berbagai dosis yang berbeda berpengaruh nyata terhadap performa pertumbuhan dan nilai FCR udang vaname, tetapi tidak mempengaruhi tingkat kelangsungan hidup (SR) udang vaname.

Secara keseluruhan semua pakan udang yang diberikan perlakuan ekstrak daun petai cina dapat memberikan laju pertumbuhan spesifik, pertumbuhan bobot mutlak, dan pertumbuhan panjang mutlak benih udang vaname yang lebih baik jika dibandingkan perlakuan kontrol (Gambar 4.,5. dan 6.). Diduga bahwa pemberian ekstrak daun petai cina dapat meningkatkan pertumbuhan udang vaname karena kandungan beberapa senyawa bioaktif yang terdapat pada ekstrak daun petai cina mampu meningkatkan metabolisme udang sehingga udang mampu mencerna dan menyerap makanan dengan baik.

Berdasarkan hasil uji GC-MS, ekstrak daun petai cina mengandung 3 senyawa utama yaitu glycerin (1,2,3-Propanetriol), erythritol (1,2,3,4Tetrahydroxybutane) dan inositol (mome inositol) (Gambar 1). Senyawa glycerin muncul pada peak 1 dengan waktu retensi 7,963 dan luas area sebesar $41,27 \%$. Glycerol berperan sebagai antibakteri yang dapat membunuh bakteri penyebab penyakit pada udang sehingga udang menjadi sehat dan dapat memaksimalkan penyerapan nutrisi pada pakan. Selain itu kandungan glycerin pada ekstrak daun petai cina ini dimanfaatkan oleh udang dalam proses metabolisme dan mengubah glycerol menjadi lemak tubuh. Lemak tubuh digunakan sebagai sumber energi yang mudah dicerna dan memberikan energi yang lebih besar dibandingkan protein dan karbohidrat. Hal ini sejalan dengan hasil penelitian Suryaningrum et. al., (2017), bahwa gliserol dimanfaatkan oleh tubuh ikan nila dalam proses metabolisme dan mengubah gliserol menjadi lemak tubuh. Kandungan glycerin dalam ekstrak daun petai cina ini juga menambah tingkat kecernaan energi pakan. Menurut Suryaningrum et. al., (2017), bahwa gliserol akan diserap ketika berada di usus halus. Setelah itu gilerol akan masuk ke dalam sistem peredaran darah untuk disintesis menjadi glukosa oleh hati dan jaringan. Proses ini disebut sebagai glukoneogenesis, yaitu energi diproduksi melalui jalur glikolisis dan siklus asam sitrat.

Selanjutnya senyawa erythritol muncul pada peak 4 dengan waktu retensi 9,604 dan luas area sebesar $21,66 \%$. Erythritol adalah gula alkohol yang dapat digunakan untuk mengganti glukosa. Erythritol merupakan golongan gula alkohol alami yang berasal dari reduksi glukosa. Kandungan gula alkohol ini digunakan sebagai energi dalam tubuh udang. Glukosa akan mengalami proses metabolisme dan menghasilkan cadangan energi untuk udang. Menurut Lestari et. al., (2019), bahwa apabila glukosa sebagai sumber energi dalam pakan tidak dimanfaatkan maka akan disimpan sebagai cadangan energi yang berupa glikogen. Glikogen ini dihasilkan dari proses metabolisme glukosa yang terdapat pada pakan tadi melalui mekanisme glikogenesis. Jadi kadar glikogen yang meningkat menunjukkan adanya glukosa darah setelah energi untuk metabolisme terpenuhi yang akan dikonversi menjadi glikogen yang disimpan pada otot dan tubuh udang vaname.

Kemudian senyawa inositol yang muncul pada peak 12 dengan waktu retensi 11,373 dan luas area 11,05\%. Menurut Kumar et. al., (2012), inositol memiliki fungsi atau aktivitas biologis sebaga antineuropati, kolesterolitik, lipotropik dan pemanis. Prihantini (2018) menambahkan, kandungan mome inositol, sophoridane dan asam lemak dimungkinkan memiliki peran dalam aktivitas antibakteri. Diduga bahwa kandungan inositol yang terdapat dalam ekstrak daun petai cina ini berperan sebagai antibakteri dan sebagai sinyal transduksi untuk insulin. Sementara insulin itu sendiri merupakan hormon yang berperan dalam pertumbuhan. Inositol dapat menambah nafsu makan udang, menjaga daya tahan tubuh udang, serta meningkatkan kualitas pakan yang digunakan. Hal ini sesuai dengan pernyataan Lestari et. al., (2016), bahwa inositol sebagai suatu senyawa biomolekul sangat berperan dalam pertumbuhan dan pemeliharaan tubuh, serta proses reproduksi. Kebutuhan kalori dalam proses 
metabolisme, pertumbuhan, dan peningkatan daya tahan tubuh untuk bertahan hidup juga dapat dipenuhi dengan adanya inositol. Beberapa ikan yang kekurangan inositol akan menunjukkan gejala nafsu makan yang menurun, pengosongan lambung terlambat, anemia, dan terhambatnya pertumbuhan.

Pemberian ekstrak daun petai cina dapat mempengaruhi pertumbuhan udang vaname, namun terdapat kecenderungan peningkatan pertumbuhan udang yang tidak sejalan dengan meningkatnya konsentrasi pemberian ekstrak daun petai cina. Hasil penelitian ini menunjukkan bahwa pemberian ekstrak daun petai cina sampai dengan konsentrasi $2 \% \mathrm{v} / \mathrm{w}$ (P3) memberikan pertumbuhan udang vaname yang semakin meningkat tetapi kemudian menurun pada pemberian ekstrak daun petai cina $3 \%(\mathrm{P} 4)$, walaupun pertumbuhan pada perlakuan P4 ini masih lebih baik jika dibandingkan dengan perlakuan kontrol (P1). Hal ini diduga bahwa konsentrasi ekstrak daun petai cina yang dapat ditolerir dalam pakan udang hanya sampai konsentrasi $2 \%$ v/w saja dan apabila diberikan di atas konsentrasi $2 \% \mathrm{v} / \mathrm{w}$ maka kandungan senyawa bioaktif yang ada pada ekstrak daun petai cina ini akan sulit diabsorbsi oleh tubuh udang sehingga senyawa aktif ini tidak dapat memberikan efek aktifitasnya sebagai imunostimulan atau akan berperan sebagai penghambat metabolisme udang. Hal ini sesuai dengan pernyataan Ridlo dan Pramesti (2009) bahwa aktifitas suatu senyawa aktif akan muncul ketika telah mencapai lokasi tagetnya, artinya untuk memberikan efek aktifitasnya maka senyawa aktif tersebut harus masuk kedalam darah setelah dari saluran pencernaan untuk dapat dibawa/ditransfer ke lokasi targetnya. Efek imunostimulan dapat ditimbulkan apabila jumlah senyawa aktif yang diberikan lebih kecil dari jumlah minimal yang diperlukan, namun sebaliknya apabila diberikan dalam jumlah yang terlalu tinggi maka tidak akan menghasilkan efek bahkan dapat bersifat sebagai inhibitor

Pertumbuhan udang vaname pada perlakuan dengan konsentrasi ekstrak daun petai cina 3\% v/w (P4) ini juga menurun diduga karena tingginya serat kasar yang terdapat pada pakan yang dapat mempengaruhi daya cerna udang vaname. Akibatnya udang tidak dapat menyerap protein pada pakan secara maksimal untuk digunakan dalam proses pertumbuhan walaupun kadar protein tertinggi terdapat pada pakan perlakuan ekstrak daun petai cina 3\% v/w (P4) tersebut, yaitu 2,88\% (Tabel 2).
Menurut Rahman et. al., (2018) bahwa serat kasar merupakan salah satu komponen dalam makanan yang bersumber dari tanaman. Ketika di dalam saluran pecernaan biasanya serat kasar sangat tahan terhadap pemecahan oleh enzim sehingga menyebabkan serat kasar tersebut menjadi sulit diabsorbsi/diserap. Hal ini berkaitan dengan kemampuan udang dalam mencerna makanannya sehingga akan berpengaruh terhadap pertumbuhan udang vaname.

Kecenderungan peningkatan pertumbuhan udang vaname yang lebih baik pada pakan dengan penambahan ekstrak daun petai cina $1 \%$ v/w (P2) dan $2 \% \mathrm{v} / \mathrm{w}$ (P3) ini juga diduga karena kandungan karbohidrat pakan yang lebih tinggi dibandingkan perlakuan penambahan ekstrak daun petai cina $3 \%$ v/w (P4) dan kandungan lemak kasar yang lebih tinggi pada pakan jika dibandingkan perlakuan kontrol (P1). Karbohidrat dan lemak pada pakan dapat dimanfaatkan sebagai sumber energi yang baik sehingga protein pada pakan dapat dioptimalkan pemanfaatannya untuk pertumbuhan udang vaname. Mekanisme ini dikenal dengan istilah "protein sparing effect". Karbohidrat dan lemak akan menggantikan protein sebagai sumber energi, sehingga energi yang berasal dari protein dapat digunakan untuk menunjang pertumbuhan udang vaname. Hal ini sesuai dengan pernyataan Munisa et. al., (2015), bahwa dibandingkan protein dan karbohidrat maka lemak merupakan sumber energi yang memiliki nilai cukup tinggi sehingga dapat menunjang pertumbuhan ketika terdapat dalam pakan. Hal ini disebabkan karena ketika penggunaan lemak sebagai "protein sparing effect" maka lemak secara tidak langsung dapat menggantikan peran protein sebagai sumber energi. Akibatnya energi yang berasal dari protein dapat dialihkan pemanfaatan secara optimal untuk menunjang pertumbuhan. Sanjayasari dan Kasprijo (2010) juga menyatakan bahwa penggunaan karbohidrat dan lemak sebagai "protein sparing effect" dapat menyebabkan protein yang terkandung dalam pakan dapat digunakan untuk pertumbuhan. Hal ini disebabkan karena fungsi protein untuk aktifitas metabolisme dan maintanance tubuh dapat diseimbangkan dan tidak hanya bertumpu pada protein. Munisa et. al., (2015) menambahkan, bahwa energi yang ada akan digunakan terlebih dahulu untuk pemeliharaan tubuh, metabolisme, dan aktivitas. Selanjutnya apabila terjadi kelebihan 
energi bebas setelah energi digunakan pada semua aktivitas tadi barulah akan digunakan untuk pertumbuhan. Dengan kata lain bahwa protein akan digunakan untuk membentuk jaringan baru setelah energi dari minyak maupun lemak telah mencukupi aktivitas lainya terlebih dahulu. Pada saat ini maka terjadilah proses pertumbuhan.

Pemanfaatan protein untuk pertumbuhan pada udang vaname yang cukup baik pada semua perlakuan pakan dengan pemberian ekstrak daun petai cina jika dibandingkan dengan perlakuan tanpa pemberian ekstrak daun petai cina (kontrol) ini juga didukung oleh nilai rasio konversi pakan (FCR). Nilai FCR merupakan perbandingan antara jumlah pakan yang digunakan dengan jumlah bobot udang selama pemeliharaan. Hal ini sesuai dengan pernyataan Mardhiana, et. al., (2017), bahwa laju pertumbuhan dan bobot tubuh ikan sangat dipengaruhi oleh rasio konversi pakan. Ridlo dan Subagiyo (2013), menambahkan bahwa berarti semakin banyak pakan yang tidak diubah menjadi biomassa udang maka nilai FCR akan semakin tinggi,. Jika nilai FCR tinggi maka menunjukkan bahwa perlakuan yang diberikan ternyata semakin tidak efektif dan tidak efisien.

Nilai FCR yang diperoleh pada penelitian ini masih berada pada kisaran rasio konversi pakan yang baik, yaitu berkisar 0,7-1. Semakin kecil nilai konversi pakannya maka menunjukkan semakin kecil atau sedikit jumlah pakan yang diberikan sehingga pakan semakin efisien. Menurut Zainuddin et. al., (2008), bahwa semakin baik mutu pakan maka semakin tinggi tingkat kecernaan pakan tersebut sehingga semakin kecil atau rendah nilai rasio konversi pakan. Kualitas pakan untuk pertumbuhan, ukuran dan kualitas air merupakan beberapa faktor yang dapat menyebabkan rendahnya nilai rasio konversi pakan.

Walaupun nilai FCR pada pakan dengan penambahan ekstrak daun petai cina $3 \%$ v/w (P4) adalah nilai terendah, namun hal ini diduga bukan menunjukkan efisiensi pakan yang baik karena tingkat kematian udang pada perlakuan ini lebih tinggi dibandingkan dengan perlakuan lainnya, tingkat kematian yang lebih tinggi ini diduga karena pengaruh pemberian ekstrak daun petai cina pada dosis yang terlalu tinggi sehingga bersifat menghambat. Pemberian ekstrak daun petai cina lebih dari $2 \%$ v/w akan menyebabkan udang mengalami gangguan metabolisme, karena senyawa aktif yang terdapat pada ekstrak daun petai cina tidak dapat diabsorbsi oleh tubuh udang. Akibatnya senyawa-senyawa tersebut tidak dapat memberikan efektifitasnya sebagai imunostimulan bagi udang melainkan akan berperan sebagai inhibitor. Sistem imun udang yang rendah menyebabkan udang mudah terserang penyakit dan kemudian akan mengalami kematian. Hal ini sesuai dengan pernyataan Ridlo dan Pramesti (2009), bahwa aktifitas suatu senyawa aktif akan muncul ketika telah mencapai lokasi tagetnya, artinya untuk memberikan efek aktifitasnya maka senyawa aktif tersebut harus masuk kedalam darah setelah dari saluran pencernaan untuk dapat dibawa/ditransfer ke lokasi targetnya. Efek imunostimulan dapat ditimbulkan apabila jumlah senyawa aktif yang diberikan lebih kecil dari jumlah minimal yang diperlukan, namun sebaliknya apabila diberikan dalam jumlah yang terlalu tinggi maka tidak akan menghasilkan efek bahkan dapat bersifat sebagai inhibitor. Oleh karena itu, pemberian ekstrak daun petai cina pada pakan udang vaname hasil penelitian ini memberikan nila FCR yang sama saja untuk perlakuan kontrol. Ekstrak daun petai cina $1 \%$ v/w (P2) dan ekstrak daun petai cina $2 \%$ v/w (P3) (Gambar 3.).

Pemberian ekstrak daun petai cina selama penelitian ini tidak mempengaruhi tingkat kelangsungan hidup udang vaname. Hal ini diduga karena kualitas air pada setiap perlakuan masih berada dalam kisaran yang optimal dan baik untuk menunjang pertumbuhan udang vaname (Tabel 3.). Nilai DO berkisar antar 6.8-7.9 $\mathrm{mg} / \mathrm{l}$, nilai DO ini masih dalam kisaran yang optimal, hal ini sesuai dengan pernyataan Purnamasari $\left(2017^{\mathrm{b}}\right)$ yang menyatakan bahwa kadar oksigen terlarut yang baik untuk budidaya udang vaname berkisar antara 4-8 $\mathrm{mg} / \mathrm{l}$. Nilai $\mathrm{pH}$ yang didapatkan selama pemeliharaan berkisar 7.9-8.2. nilai $\mathrm{pH}$ ini masih dalam kisaran yang optimal dan dapat ditoleransi oleh udang. Hal ini sesuai dengan pernyataan Purnamasari $\left(2017^{\mathrm{a}}\right)$ yang menyatakan bahwa kisaran nilai $\mathrm{pH}$ untuk pertumbuhan udang vaname berkisar antara 7,5-8,5. Selanjutnya nilai suhu selama pemeliharaan berkisar antara 27.4-28.3 ${ }^{\circ} \mathrm{C}$. nilai suhu ini masih dapat ditolerir oleh udang dan masih dalam keadaaan yang optimal. Hal ini sesuai dengan pernyataan Purnamasari $\left(2017^{\mathrm{a}}\right)$ bahwa suhu yang ideal untuk pertumbuhan udang vaname berkisar antara $28-31^{\circ} \mathrm{C}$. Nilai salinitas selama pemeliharaan masih, dapat ditolerir untuk pertumbuhan udang vaname, yaitu 
bekisar antara 29-34 ppt. Hal ini sesuai dengan pernyataan Kordi (2007) bahwa pertumbuhan yang baik didukung oleh salinitas yang berada pada kisaran antara 10-30 ppt dengan kisaran salinitas optimalnya adalah $15-25$ ppt.

Tingkat kelangsungan hidup udang vaname selama pemeliharaan berkisar antara 55\%-63\%. Tingkat kelangsungan hidup udang vaname pada perlakuan P2 (ekstrak daun petai cina $1 \% \mathrm{v} / \mathrm{w}$ ) dan P3 (ekstrak daun petai cina $2 \% \quad \mathrm{v} / \mathrm{W}$ ) memiliki persentase tertinggi yaitu $63 \%$ dan perlakuan $\mathrm{P} 4$ (ekstrak daun peta cina $3 \% \mathrm{v} / \mathrm{w}$ ) memiliki persentase terendah yaitu $55 \%$. Rendahnya tingkat kelangsungan hidup ini dapat dipengaruhi oleh faktor lingkungan dan tingkat kanibalisme yang tinggi. Tingkat kanibalisme tinggi dapat dikarenakan udang mengalami stress akibat ruang gerak yang terbatas dan persaingan dalam mendapatkan pakan. Selain itu juga dapat diakibatkan oleh proses moulting yang tidak bersamaan antara udang yang satu dengan yang lainnya. Udang yang mengalami proses moulting akan menjadi lemah dan diserang oleh udang lainnya sehingga mengalami kematian. Hal ini sesuai dengan pernyataan Ali dan Waluyo (2015), bahwa pada saat moulting biasanya terjadi penurunan nafsu makan dan daya renang udang. Kondisi ini menyebabkan sehingga udang dalam keadaan molting sangat mudah diserang. Faktor lain yang juga mempengaruhi tingkat konsumsi pakan dan kompetisi adalah keadaan media yang tidak isoosmotik (Hipo/Hiper-osmotik). Pada kondisi ini dibutuhkan energi yang lebih besar disebabkan karena energi tidak hanya digunakan untuk pertumbuhan udang tetapi juga dibutuhkan untuk proses osmoregulasi tubuhnya.

\section{KESIMPULAN}

Penambahan ekstrak daun petai cina dengan dosis yang berbeda pada pakan udang vaname dapat mempengaruhi pertumbuhan dan nilai FCR udang vaname, tetapi tidak mempengaruhi tingkat kelangsungan hidup (SR). Hasil GC-MS menunjukkan bahwa ekstrak daun petai cina mengandung senyawa glycerin, erythritol, dan inositol. Pemberian ekstrak daun petai cina sampai dengan dosis $2 \%$ v/w dapat memberikan peningkatan bobot mutlak 3,70 g, panjang mutlak $6,13 \mathrm{~cm}$, laju pertumbuhan spesifik (SGR) 5,7 g/hari dan rasio konversi pakan (FCR) 0,94 pada budidaya udang vaname.

\section{DAFTAR PUSTAKA}

Ali, Fauzan dan Waluyo, Agus. 2015. Tingkat Kelangsungan Hidup dan Pertumbuhan Udang Galah (Macrobrachium rosenbergii De Man) pada Media Bersalinitas. Limnotek, 22 (1), 42-51.

Azhar, M. H. 2013. Peranan Sumber Karbon Eksternal yang Berbeda dalam Pembentukan Bioflok dan Pengaruhnya Terhadap Kualitas Air serta Produksi pada Sistem Budidaya Udang Vaname (Litopenaeus vannamei). [Tesis]. Bogor: Institut Pertanian Bogor.

Badan Standardisasi Nasional. 2013. Pakan Buatan untuk Produksi Benih Udang Vaname (Litopenaeus vannamei). Jakarta.

Fadillah, N., Waspodo, S., dan Azhar, F. 2019.

Penambahan Ekstrak Daun Mangrove Rhizophora apiculata pada Pakan Udang Vaname (Litopenaeus vannamei) untuk Pencegahan Vibriosis. Journal of Aquaculture Science, 4 (2), 91-101.

Febriani, D., Marlina, E. dan Oktaviana, A. 2018. Total Hemosit Udang Vaname (Litopenaeus vannamei) yang dipelihara pada Salinitas 10 ppt dengan Padat Tebar Berbeda. Journal of Aquaculture Science, 3 (1), 100107.

Hanafi, R. W., Widiani, N. dan Khikmatunnaiz, M. 2012. Uji Potensi Ekstrak Daun Petai Cina (Leucaena Leucocephala) sebagai Anti Bakteri Staphylococcus Epidermidis dan Efek Penyembuhan Luka Eksisi pada Mencit Balb/C. Pelita, 8 (2), 17-25.

Isharyudono, K., Mar'ah, I., dan Jufriyah. 2019. Penggunaan Bahan Inkonvensional Sebagai Sumber Bahan Pakan. Jurnal Pengelolaan Laboratorium Pendidikan, 1 (1), 1-6.

Kementerian Kelautan dan Perikanan Republik Indonesia. 2018. Produktivitas Perikanan Indonesia. Jakarta.

Kordi, M. G. 2007. Pemeliharaan Udang Vannamei (Litopenaeus vannamei). Surabaya: Indah.

Kumar, N. R., Reddy, J. S., Gopikrishna, G., dan Solomon, K. A. 2012. GC-MS Determination of Bioactive Constituents of Cycas 
Nurul Pratiwi et al.

JURNAL SAINS dan INOVASI PERIKANAN / Journal of Fishery Science and Innovation

Vol. 5, No. 2. 72- 84, Juli 2021

Beddomei Cones. Int J Pharm Bio Sci, 3(2), 344-350.

Kuniasih, T. 2012. Potensi Daun Lamtoro (Leucaena leucocephala) Sebagai Sumber Protein Pakan Ikan Alternatif. Prosiding Indoaqua - Forum Inovasi Teknologi Akuakultur.

Kusumaningrum, P. D., Thessiana, L., dan Financia, N. G. 2017. Sistem Sterilisasi Bakteri Vibrio harveyi Menggunakan Radioisotop Cobalt-60 untuk Budidaya Udang. Jurnal Kelautan Nasional, 10 (3), 125-137.

Lubis, N. O. 2018. Substitusi Tepung Kedelai dengan Fermentasi Tepung Daun Lamtoro Gung (Leucaena leucocephala) dalam Pakan Terhadap Pertumbuhan Benih Ikan Bawal Air Tawar (Colossoma macropomum). Skripsi. Fakultas Perikanan dan Kelautan, Universitas Riau.

Lestari, D., Widiastuti, L., Nurcahyani, N., dan Susanto, G. N. 2016. Pengaruh Penambahan Sargassum sp. dan Inositol dalam Pakan terhadap Pertumbuhan dan Daya Tahan Juvenil Ikan Gurami (Osphronemus gourami Lac.). Jurnal Natur Indonesia, 16(2), 72-78.

Lestari, N. A., Aslamsyah, S., dan Zainuddin. 2019. Komposisi Kimia Tubuh dan Kadar Glikogen pada Berbagai Dosis Ubi Jalar (Ipomea batatas) sebagai Prebiotik dari Lactobacillus sp. pada Udang Vaname (Litopenaeus Vannamaei). Prosiding Simposium Nasional Kelautan dan Perikanan VI. Makassar, 21 Juni 2019, hlm 275.

Mardhiana, A., Buwono, I. D., Andriani, Y., dan Iskandar. 2017. Suplementasi Probiotik Komersil pada Pakan Buatan untuk Induksi Pertumbuhan Ikan Lele Sangkuriang (Clarias gariepinus). Jurnal Perikanan dan Kelautan, 8 (2), 133-139.

Mulqan, M., Rahimi, S. A. E., dan Dewiyanti, I. 2017. Pertumbuhan dan Kelangsungan Hidup Benih Ikan Nila Gesit (Oreochromis niloticus) pada Sistem Akuaponik Dengan Jenis Tanaman yang Berbeda. Jurnal Ilmiah
Mahasiswa Kelautan dan Perikanan Unsyiah, 2 (1), 183-193.

Munisa, Q., Subandlyono, dan Pinandoyo. 2015. Pengaruh Kandungan Lemak dan Energi yang Berbeda dalam Pakan terhadap Pemanfaatan Pakan dan Pertumbuhan Patin (Pangasius pangasius). Journal of Aquaculture Management and Technology, 4(3), 12-21.

Oktaviana, A. 2014. Kajian Pemberian Sinbiotik dengan Frekuensi Berbeda untuk Pencegahan Ko-Infeksi Infectious Myonecrosis Virus dan Vibrio harveyi pada Udang Vaname (Litopenaeus vannamei). [Tesis]. Bogor: Institut Pertanian Bogor.

Praja, M. H. dan Oktarlina.S R. Z. 2016. Uji Efektivitas Daun Petai Cina (Laucaena glauca) sebagai Antiinflamasi dalam Pengobatan Luka Bengkak. Majority, 5 (5), 86-89.

Pratama, A., Wardiyanto dan Supono. 2017. Studi Performa Udang Vaname (Litopenaeus vannamei) yang Dipelihara dengan Sistem Semi Intensif pada Kondisi Air Tambak dengan Kelimpahan Plankton yang Berbeda pada Saat Penebaran. E-Jurnal Rekayasa dan Teknologi Budidaya Perairan, 6 (1), 643652.

Prihantini, A. I., Krisnawati, Rahayu, A. A. D., Nugraheni, Y. M. M. A., dan Samawandana, G. 2018. Uji Fitokimia dan Aktivitas Antibakteri Tumbuhan Pranawija (Euchresta horsfieldii (Lesch.) Benn.). Jurnal Ilmu Kehutanan, 12, 223-233.

Purnamasari, I., Dewi, P., dan Maya, A. F. U. $2017^{\mathrm{a}}$. Pertumbuhan Udang Vaname (Litopenaeus vannamei) Di Tambak Intensif. Jurnal Enggano, 2 (1), 58-67.

Purnamasari, I., Purnama, D. dan Utami, M. A. F. 2017 . Pertumbuhan Udang Vaname (Litopenaeus vannamei) di Tambak Intensif. Jurnal Enggano, 2 (1), 58-67.

Rahman, R. Lahming, dan Fadillah, R. 2018. Evaluasi Komponen Gizi pada Pakan Udang. Jurnal Pendidikan Teknologi Pertanian, 4, $101-111$. 
84 Nurul Pratiwi et al.

JURNAL SAINS dan INOVASI PERIKANAN / Journal of Fishery Science and Innovation Vol. 5, No. 2, Juli 2021

Ridlo, A. dan Pramesti, R. 2009. Aplikasi Ekstrak Rumput Laut sebagai Agen Imunostimulan Sistem Pertahanan Non Spesifik pada Udang (Litopennaeus vannamei). Ilmu Kelautan, 14(3), 133-137.

Ridlo, A. dan Subagiyo. 2013. Pertumbuhan, Rasio Konversi Pakan dan Kelulushidupan Udang Litopenaeus vannamei yang Diberi Pakan dengan Suplementasi Prebiotik FOS (Fruktooligosakarida). Buletin Oseanografi Marina, 2 (4), 1-8.

Sanjayasari, D. dan Kasprijo. 2010. Estimasi Nisbah Protein-Energi Pakan Ikan Senggaringan (Mystus nigriceps) Dasar Nutrisi untuk Keberhasilan Domestikasi. Jurnal Perikanan dan Kelautan, 15(2), 8997.

Setyono, B. D. H., Azhar, F., dan Paryono. 2019. Pengaruh Aplikasi Bioflock yang Dikombinasikan dengan Probiotik Terhadap Performa Pertumbuhan Udang Vaname. 9Buletin Veteriner Udayana, 11 (1), 7-13.
Suci, A. N. 2018. Efektivitas Pemberian Beberapa Bahan Herbal untuk Menekan Pertumbuhan Vibrio parahaemolyticus pada Tambak Udang Vaname. [Skripsi]. Bandar Lampung: Universitas Lampung.

Suryaningrum, L. H., Mulyasari, dan Samsudin, R. 2017. Pengaruh Penambahan Gliserol pada Pakan terhadap Pertumbuhan dan Kelangsungan Hidup Ikan Nila (Oreochromis niloticus). Berita Biologi, 16(2), 157-165.

Zainuddin, Aslamyah, S. dan Hadijah. 2008. Efek dari Perbedaan Sumber Karbohidrat Pakan Terhadap Kualitas Air, Komposisi Proksimat dan Kandungan Glikogen Juvenil Udang Vannamei Litopenaeus vannamei (Boone, 1931). Jurnal Ilmiah Samudra Akuatika, 2 (1), 1-8 